\title{
Kajian Keputusan Badan Usaha terhadap Kepesertaan Jaminan Kesehatan Nasional di Kabupaten Jember (Corporations Decision on the Involvement in National Health Insurance in Jember)
}

\author{
Galih Dwi Damaiyanti, Eri Witcahyo, Ragil Ismi Hartanti \\ Bagian Administrasi dan Kebijakan Kesehatan \\ Fakultas Kesehatan Masyarakat, Universitas Jember \\ Jalan Kalimantan 37 Jember 68121 Tegal Boto Jember 68121 \\ e-mail: galihdwidamaiyanti@gmail.com
}

\begin{abstract}
National Health Insurance (NHI) is a part of the National System of Social Insurance which is estabilished by Social Agencies of Health. One of the problems in NHI is corporations membership. All employers such as State-Owned Enterprise (BUMN), large, medium or small scale corporations are the target member of NHI, at least by January $1^{\text {st }} 2015$, but this target has yet to be actualized. The number of corporation in Jember, by February 2017, has reached 2451 and only 954 corporations were registered (38,92\%). The objectives of this study was to assess corporations decision on $\mathrm{NHI}$ membership. The study applied qualitative case study. Informant determination technique uses purposive sampling. The results showed that the components of input was not appropriate. Knowledge, perception on product characteristics and need of informants were low, reference group posed significant influence on the corporations decision making in taking part in NHI. The decision making process has yet optimal in the problem or needs analysis and alternative evaluation, corporations tended to be passive in searching information. The output was membership classification of corporations in NHI has yet to be actualized.
\end{abstract}

Key Words : National Health Insurance, Corporation

\begin{abstract}
Abstrak
Program JKN merupakan bagian dari SJSN yang diselenggarakan oleh BPJS Kesehatan dengan menggunakan mekanisme asuransi kesehatan sosial yang bersifat wajib. Salah satu permasalahan pada program JKN adalah kepesertaan badan usaha. Seluruh pemberi kerja pada BUMN, usaha besar, usaha menengah, dan usaha kecil menjadi target kepesertaan JKN paling lambat pada 1 Januari 2015, akan tetapi target tersebut belum terpenuhi. Jumlah badan usaha di Kabupaten Jember sampai pada Februari 2017 sebanyak 2451 badan usaha dan yang telah terdaftar menjadi peserta hanya 954 badan usaha (38,92\%). Tujuan penelitian ini adalah mengkaji keputusan badan usaha terhadap kepesertaan JKN menggunakan teori sistem yang dilihat dari input, proses dan output dari badan usaha. Penelitian ini merupakan penelitian kualitatif dengan pendekatan studi kasus. Teknik penentuan informan yang digunakan adalah purposive sampling. Hasil penelitian menunjukkan bahwa pada input, komponenkomponennya masih tidak sesuai yaitu pengetahuan, persepsi terhadap karakteristik produk dan kebutuhan informan masih rendah, kelompok referensi mempunyai pengaruh besar untuk tidak menjadi peserta program JKN. Proses pengambilan keputusan belum optimal pada tahap pengenalan masalah/kebutuhan dan evaluasi alternatif badan usaha serta perilaku pencarian informasi yang masih pasif. Outputnya pentahapan kepesertaan badan usaha pada program JKN belum tercapai.
\end{abstract}

Kata kunci : Jaminan Kesehatan Nasional, Badan Usaha 


\section{Pendahuluan}

JKN merupakan program yang bersifat wajib dan merupakan bentuk komitmen pemerintah terhadap pelaksanaan jaminan kesehatan masyarakat Indonesia seluruhnya. Impelementasi JKN oleh BPJS Kesehatan dimulai pada tanggal 1 Januari 2014 [2]. Salah satu tugas dari BPJS Kesehatan dalam pelaksanaan program JKN ialah melakukan dan/atau menerima pendaftaran peserta, serta memberikan informasi mengenai penyelenggaraan program Jaminan Sosial kepada peserta dan masyarakat [12].

BPJS menyatakan bahwa pemberi kerja secara bertahap wajib mendaftarkan dirinya dan pekerjanya sebagai peserta kepada BPJS [12]. Berdasarkan Pasal 6 Perpres No. 111 tahun 2013 juga menyebutkan bahwa BPJS Kesehatan menargetkan pada seluruh pemberi kerja pada Badan Usaha Milik Negara (BUMN), usaha besar, usaha menengah, dan usaha kecil paling lambat 1 Januari 2015 telah mendaftarkan seluruh pegawainya pada program JKN. Berdasarkan target tersebut dapat diartikan bahwa seluruh badan usaha yang berada di Indonesia wajib mendaftarkan karyawannya pada program JKN paling lambat 1 Januari 2015.

Selama tiga tahun terakhir, BPJS Kesehatan terus mengalami defisit yang terus meningkat dari tahun ke tahun. Pada tahun 2014 defisit yang dialami BPJS Kesehatan mencapai Rp 3,3 triliun, pada tahun 2015 defisit meningkat menjadi $\mathrm{Rp}$ 5,7 triliun, dan pada tahun 2016 defisit mencapai Rp 9,7 triliun. Untuk semester pertama tahun 2017, defisit BPJS Kesehatan telah mencapai $\mathrm{Rp}$ 5,8 triliun [5]. Terdapat beberapa solusi yang bisa dilakukan BPJS Kesehatan untuk mengurangi defisit pada Dana Jaminan Sosial (DJS) salah satunya yaitu dengan cara meningkatkan kepesertaan Pekerja Penerima Upah (PPU), khususnya pada sektor non pemerintah atau swasta. Data BPJS Kesehatan per 30 Juni 2017 untuk jumlah peserta PPU sebanyak 10,9 juta jiwa, sedangkan jumlah peserta PPU BPJS Ketenagakerjaan mencapai 24 juta jiwa. Jika BPJS Kesehatan mampu meningkatkan jumlah peserta PPU sama dengan jumlah peserta PPU BPJS Ketenagakerjaan atau menjadi 20 juta jiwa, iuran yang terkumpul dari peserta PPU tersebut selama setahun bisa mencapai Rp 40 triliun sehingga bisa diperkirakan anggaran DJS yang defisit bisa menjadi surplus [1]. Berdasarkan data tersebut dapat diketahui bahwa peran badan usaha sangat besar untuk menutup terjadinya defisit pada BPJS Kesehatan.
Menurut BPJS Kesehatan, di Indonesia terdapat 144 BUMN yang telah terdaftar sebagai peserta JKN-KIS tapi hanya 50 BUMN yang sudah mendaftarkan $100 \%$ karyawan dan keluarganya sehingga diketahui bahwa target kepesertaan badan usaha untuk BUMN belum terpenuhi. Jumlah badan usaha yang berada di Divisi Regional VII BPJS Kesehatan Jawa Timur adalah sebanyak 36.000 badan usaha dan yang tergabung sebagai peserta sebanyak 26.000 atau $72,22 \%$. Jumlah badan usaha yang ada di Kabupaten Jember sampai pada tahun 2016 sebanyak 2451 badan usaha dan yang telah terdaftar hanya 954 badan usaha atau sebesar $38,92 \%$. Hal tersebut menunjukkan bahwa cakupan kepesertaan JKN khususnya pada badan usaha di Kabupaten Jember masih belum tercapai.

UU No. 24 Tahun 2011 tentang BPJS menyebutkan pemberi kerja secara bertahap wajib mendaftarkan dirinya, pekerjanya berikut anggota keluarganya sebagai peserta kepada BPJS. Pemberi kerja diantaranya adalah orang perseorangan, pengusaha, badan hukum atau badan lainnya yang mempekerjakan tenaga kerja. Keuntungan yang didapatkan badan usaha dengan mengikutsertakan pekerjanya pada program JKN adalah badan usaha terhindar dari sanksi administratif yang diberikan oleh BPJS Kesehatan. Meskipun mendapatkan keuntungan tersebut, tapi pada kenyataannya masih banyak badan usaha yang belum mendaftarkan pekerjanya pada program JKN. Hal tersebut menunjukkan bahwa masih kurangnya minat badan usaha sebagai konsumen untuk menjadi peserta program JKN.

Perilaku konsumen adalah studi tentang bagaimana individu, kelompok, organisasi dan proses yang dilakukan untuk memilih, mengamankan, menggunakan dan menghentikan produk, jasa, pengalaman atau ide untuk memuaskan kebutuhannya dan dampaknya terhadap konsumen dan masyarakat yang mempelajari dampak dari proses dan aktivitas yang dilakukan konsumen ke konsumen lain maupun masyarakat [10]. Dalam prosesnya untuk memilih, menggunakan atau menghentikan jasa tersebut, terdapat dua faktor yang mempengaruhi yaitu faktor internal dan eksternal [4]. Selanjutnya, kedua faktor tersebut akan mempengaruhi dalam proses pengambilan keputusan pembelian. Terdapat lima tahap pembelian konsumen yaitu pengenalan kebutuhan, pencarian informasi, evaluasi alternatif, keputusan pembelian, dan perilaku pasca pembelian [3].

Penelitian ini bertujuan untuk mengkaji keputusan badan usaha terhadap kepesertaan Jaminan Kesehatan Nasional di Kabupaten Jember 


\section{Metode Penelitian}

Jenis penelitian yang digunakan adalah penelitian kualitatif dengan desain studi kasus (case studies). Penelitian ini dilakukan di Kabupaten Jember. Informan pada penelitian ini adalah pemilik dan pekerja UD PJ, pengawas dan pekerja UD PA, direktur dan pekerja CV SAJ, serta petugas Reationship Officer (RO) dan petugas pemeriksa BPJS Kesehatan Kabupaten Jember. Penentuan informan penelitian ini menggunakan metode purposive sampling. Penelitian ini dilaksanakan pada bulan OktoberDesember 2017.

Sumber data penelitian ini adalah data primer dan data sekunder. Data primer yaitu dari hasil wawancara mendalam dan observasi. Sedangkan data sekunder yaitu dari hasil dokumentasi yaitu data jumlah pekerja UD PJ, UD PA, CV SAJ, dari Dinas Perijinan Perdagangan dan ESDM yaitu jumlah badan usaha yang terdaftar di Kabupaten Jember, serta dari BPJS Kesehatan Kabupaten Jember yaitu jumlah dan daftar badan usaha yang telah menjadi peserta program JKN. Teknik pengumpulan data menggunakan wawancara mendalam (in-depth interview), dokumentasi dan observasi. Teknik penyajian data penelitian ini diungkapkan dalam bentuk kalimat serta uraian-uraian dan cerita pendek. Analisis data yang dilakukan dalam penelitian ini adalah reduksi data, penyajian data dan penarikan kesimpulan.

\section{Hasil dan Pembahasan}

Penelitian ini menjadikan tiga badan usaha skala menengah dengan risiko kecelakaan kerja tinggi yang belum mendaftar program JKN sebagai tempat penelitian. Badan usaha pertama yang dijadikan sebagai tempat penelitian adalah UD PJ yang merupakan badan usaha yang berdiri sejak tahun 1985 yang bergerak di bidang pengelasan dan jasa konstruksi baja. Jumlah pekerja pada badan usaha tersebut saat ini sebanyak 22 pekerja. Pekerja di badan usaha tersebut tidak menggunakan APD apapun, sehingga kondisi tersebut memungkinkan pekerja mengalami risiko Kecelakaan Akibat Kerja (KAK) maupun Penyakit Akibat Kerja (PAK). Jaminan sosial yang sudah digunakan oleh badan usaha ini hanya jaminan sosial dari BPJS Ketenagakerjaan, sedangkan Jaminan Kesehatan dari BPJS Kesehatan belum terdaftar sehingga risiko PAK pada pekerja belum bisa dilindungi sepenuhnya oleh badan usaha.

Badan usaha kedua yang dijadikan sebagai tempat penelitian adalah UD PA yang berdiri sejak tahun 1980an. UD PA merupakan usaha yang bergerak di bidang usaha kerajinan aluminium dan kaca dengan jumlah pekerjanya sebanyak 13 pekerja. Badan usaha tersebut belum tergabung dalam jaminan sosial apapun sehingga tidak ada jaminan terhadap risiko KAK maupun PAK yang terjadi pada pekerjanya.

Badan usaha yang ketiga adalah CV SAJ yang berdiri sejak tahun 1970an yang bergerak di bidang penyedia bahan dan material konstruksi serta jasa konstruksi dengan jumlah pekerjanya sebanyak 27 pekerja. Pekerja di badan usaha tersebut tidak menggunakan APD apapun, sehingga kondisi tersebut memungkinkan pekerja mengalami risiko KAK maupun PAK. Jaminan sosial yang sudah digunakan oleh badan usaha ini hanya jaminan sosial dari BPJS Ketenagakerjaan, sedangkan Jaminan Kesehatan dari BPJS Kesehatan belum terdaftar.

a. Input

Input adalah unsur masukan yang digunakan untuk proses pengambilan keputusan, terdiri dari faktor internal (pengetahuan, persepsi terhadap karakteristik produk, kebutuhan) dan faktor eksternal (agama, kebijakan, kelompok referensi).

Pengetahuan di sini adalah pengetahuan pemilik badan usaha dan pekerjanya tentang pemahaman informasi program JKN. Didapatkan tingkat pengetahuan informan masih rendah karena badan usaha dan pekerjanya hanya dapat menyebutkan secara garis besar tentang pogram JKN tapi tidak bisa menjelaskan dan menjabarkan informasi secara tepat. Pimpinan badan usaha belum memahami pentingnya program JKN untuk perusahaannya maupun untuk pekerjanya, mereka juga tidak memahami dengan baik sanksi administratif yang akan didapatkan bila tidak mendaftarkan seluruh pekerjanya pada program JKN. Pekerja pada badan usaha juga tidak mengetahui bila terdapat kebijakan yang mewajibkan pemberi kerja untuk memberikan jaminan sosial untuk seluruh pekerjanya. Berdasarkan penelitian menyatakan bahwa rendahnya pengetahuan masyarakat mengenai program JKN mempengaruhi akses masyarakat pada BPJS Kesehatan [13].

"Kalau saya lihatnya ya, kebanyakan BU itu cuma tahu kulit-kulitnya aja. Maksud kulit-kulitnya ini ya mereka tahu kalau program JKN itu punya BPJS Kesehatan, terus manfaatnya bisa untuk melindungi saat mereka sakit, bahkan ada juga yang tahu tentang sanksi tapi mereka berpikirnya, ya sudah lah kan perusahaan yang lain juga banyak 
yang belum daftar. Jadi seperti itu." (Informan 1, 23 Tahun)

Pengetahuan individu yang rendah dapat disebabkan karena mereka tidak mendapatkan pendidikan dasar yang baik dan kurangnya akses informasi atau sosialisasi tentang program JKN dari BPJS Kesehatan. Terdapat dua macam sosialisasi yang dilakukan oleh pihak BPJS Kesehatan, yaitu sosialisasi langsung dan sosialisasi tidak langsung. Sosialisai langsung dilakukan dengan suatu metode yang dinamakan metode canvassing. Metode canvassing adalah metode pendekatan yang dilakukan oleh pihak BPJS Kesehatan dengan cara mendatangi secara langsung badan usaha, memberikan informasi tentang program JKN dengan sedikit penekanan berupa peringatan terkait adanya sanksi bagi badan usaha yang tidak mendaftarkan seluruh pekerjanya pada program JKN. Sosialisasi tidak langsung dilakukan apabila suatu badan usaha menyadari pentingnya BPJS Kesehatan tapi masih belum memahami program apa yang dilaksanakan, tujuan, manfaat, dll, sehingga badan usaha mengundang pihak BPJS Kesehatan untuk melakukan sosialisasi pada seluruh pekerjanya.

Persepsi terhadap karakteristik produk adalah persepsi badan usaha terkait program JKN yang dapat mempengaruhi secara langsung pada keputusannya untuk membeli. Terdapat kesenjangan persepsi antara pimpinan badan usaha dengan pihak BPJS Kesehatan terkait pelayanan kesehatan dan iuran bagi peserta program JKN. Menurut badan usaha pelayanan kesehatan yang diberikan oleh fasilitas kesehatan tidak sesuai dengan harapan, tapi BPJS Kesehatan menyatakan ada kemungkinan peserta yang tidak melaksanakan kewajibannya sebagai peserta sehingga ada tindakan yang dilakukan oleh pihak fasilitas kesehatan. Kemudian badan usaha juga beranggapan bahwa iuran yang dibebankan terlalu mahal dan memberatkan padahal BPJS Kesehatan menyatakan bahwa pembebanan tarif yang ditentukan lebih murah dari hasil analisis aktuarialnya karena pada kenyataannya saat ini BPJS Kesehatan mengalami defisit. Berdasarkan hal tersebut disimpulkan bahwa persepsi badan usaha terhadap karakteristik program JKN masih rendah.

Kebutuhan terhadap program JKN adalah penilaian atau anggapan informan yang dipengaruhi gambaran diri sendiri, situasi, serta kebutuhannya terhadap kepesertaan pada program JKN. Hasil penelitian ini menunjukkan kebutuhan badan usaha terhadap program JKN masih rendah dilihat dari persepsi manfaat pimpinan badan usaha.
"..Ya yang lebih merasakan nanti malah anak-anak mbak, kalau perusahaan ya mungkin nggak kena sanksi itu.." (Informan 3, 45 tahun)

Badan usaha merasa bahwa yang akan lebih merasakan manfaat dari program JKN adalah pekerjanya, sedangkan badan usaha hanya akan mendapat manfaat dari terhindarnya risiko perusahaan. Padahal manfaat yang akan didapatkan badan usaha yang menjadi peserta program JKN adalah badan usaha bisa terhindar dari risiko finansial apabila pekerjanya mengalami sakit.

Hasil wawancara mendalam diketahui bahwa sosialisasi menjadi faktor yang mempengaruhi kebutuhan informan. Badan usaha menginginkan pihak BPJS Kesehatan untuk mendatangi secara langsung perusahaannya untuk memberikan sosialisasi. Faktor lainnya adalah adanya perbaikan mutu pelayanan kesehatan di fasilitas kesehatan. Berdasarkan penelitian menyatakan bahwa kebutuhan (need) merupakan prediktor terkuat dalam upaya pemanfaatan pelayanan kesehatan di rumah sakit [8]. Semakin baik mutu pelayanan kesehatan yang diberikan oleh fasilitas kesehatan semakin tinggi juga kebutuhan yang dirasakan oleh seseorang, sehingga kebutuhan akan pelayanan kesehatan yang terjamin tersebut menjadi salah satu faktor yang dapat mempengaruhi kebutuhan informan untuk mengikuti program JKN.

Agama memberikan pedoman ajaran mengenai apa yang harus dilakukan dan apa yang tidak boleh dilakukan oleh para pemeluknya. Ajaran-ajaran agama tersebut akan mempengaruhi sikap, motivasi, persepsi, dan perilaku konsumen dalam mengkonsumsi barang dan jasa. Salah satu pimpinan badan usaha beranggapan bila program JKN lebih banyak mudharatnya (kerugian) yaitu bahwa program JKN mengandung unsur gharar (ketidakjelasan), riba (kelebihan antara yang diterima dan yang diberikan), dan pengelolaan keuangannya yang tidak sesuai dengan prinsip syariah. Pandangan pimpinan badan usaha tersebut sejalan dengan pandangan Majelis Ulama Indonesia (MUI) yang disebutkan pada Keputusan Komisi B 2 Masail Fiqhiyyah Mu'ashirah (Masalah Fikih Kontemporer) ljtima' Ulama Komisi Fatwa Se-Indonesia V Tahun 2015 tentang Panduan Jaminan Kesehatan Nasional dan BPJS Kesehatan, bahwa program JKN termasuk modus transaksional yang dilakukan BPJS, khususnya BPJS Kesehatan dari perspektif ekonomi islam dan fikih muamalah. Tapi hasil ljtima' tersebut masih dalam bentuk rekomendasi untuk disempurnakan oleh pihak BPJS Kesehatan. 
Jadi MUI tidak pernah memberi label haram pada BPJS Kesehatan.

\begin{abstract}
"Kalau menurut saya ya sudah baik, kan niatnya pemerintah itu mbantu orang-orang yang nggak mampu. Saya juga merasa untung bisa dibantu sama pemerintah." (Informan 7, 25 tahun)
\end{abstract}

Sebagian besar informan menyatakan mereka menilai program JKN bukan dari faktor agama melainkan lebih pada segi kebermanfaatan program tersebut. Ungkapan tersebut sudah sesuai dengan salah satu prinsip program JKN yaitu prinsip kegotongroyongan. Dapat disimpulkan bahwa faktor agama tidak mempengaruhi dalam pengambilan keputusan sebagian besar informan terhadap kepesertaannya pada program JKN. Berdasarkan penelitian menyatakan bahwa latar belakang konsumen yang terdiri dari kebangsaan, agama, kelompok ras, dan wilayah geografis tidak terlalu mempengaruhi proses pengambilan keputusan pembelian asuransi. Meskipun faktor budaya memiliki arah hubungan positif terhadap keputusan pembelian konsumen, tapi faktor budaya memiliki pengaruh yang tidak signifikan [9].

Kebijakan adalah serangkaian tindakan yang mempunyai tujuan tertentu yang harus diikuti dan dilakukan oleh para pelakunya untuk memecahkan suatu masalah. UU No. 24 Tahun 2011 tentang BPJS menyebutkan pemberi kerja secara bertahap wajib mendaftarkan dirinya, pekerjanya berikut anggota keluarganya sebagai peserta kepada BPJS.

"Ini kan syaratnya direktur dan satu pegawai yang wajib mendaftar mbak ya.." (Informan 5, 30 tahun)

Seluruh badan usaha yang dijadikan objek penelitian ini belum menjadi peserta program JKN dengan alasan keberatan untuk mendaftarkan seluruh pekerjanya, tidak mengetahui adanya kebijakan tersebut, serta ada juga yang beranggapan yang wajib didaftarkan pada program JKN hanya pemberi kerja dan satu pekerjanya. Berdasarkan uraian diatas dapat disimpulkan bahwa pemahaman badan usaha mengenai kebijakan yang terkait dengan program JKN masih rendah.

Kelompok referensi (reference group) merupakan semua kelompok yang memiliki pengaruh langsung (tatap muka) atau tidak langsung terhadap perilaku orang (sikap) [3]. Kelompok referensi berfungsi sebagai referensi bagi seseorang dalam keputusan pembelian dan konsumsi. Kelompok referensi yang dipercaya oleh sebagian besar pimpinan badan usaha untuk mengambil keputusan adalah anggota keluarga yang menjadi rekannya dalam bekerja. Anggota keluarga termasuk dalam kelompok acuan primer yang merupakan kelompok dengan keanggotaan yang terbatas, interaksi yang terjadi antar anggota secara langsung dan memiliki ikatan emosional. Selain kelompok acuan primer juga ada kelompok acuan formal yaitu MUI bagi pimpinan badan usaha yang mempunyai keyakinan sejalan dengan Keputusan Komisi B 2 Masail Fiqhiyyah Mu'ashirah (Masalah Fikih Kontemporer) ljtima' Ulama Komisi Fatwa Se-Indonesia V Tahun 2015 tentang Panduan Jaminan Kesehatan Nasional dan BPJS Kesehatan. Berdasarkan hal tersebut disimpulkan bahwa kelompok referensi mempunyai pengaruh besar terhadap keputusan informan dalam kepesertaannya pada program JKN. Berdasarkan penelitian menyatakan bahwa kelompok acuan mempengaruhi keputusan pembelian secara signifikan [15].

\section{b. Proses}

Proses dalam penelitian ini berupa tahapan badan usaha dalam melakukan pengambilan keputusan terhadap kepesertaannya pada program JKN. Perilaku proses pengambilan keputusan diawali dengan pengenalan masalah atau kebutuhan, pencarian kebutuhan, kemudian evaluasi alternatif, selanjutnya keputusan membeli, dan yang terakhir adalah perilaku pasca pembelian. Tapi pada penelitian ini tahap perilaku pasca pembelian tidak dikaji karena objek penelitian ini adalah badan usaha yang tidak menjadi peserta program JKN.

Proses pembelian dimulai ketika pembeli mengenali masalah atau kebutuhannya. Pengenalan masalah atau kebutuhan tersebut dapat dicetuskan oleh rangsangan internal dan eksternal yang berada pada faktor input. Pada faktor input, pengetahuan informan tentang program JKN masih rendah, persepsi pimpinan badan usaha terhadap karakteristik program JKN masih rendah, kebutuhan badan usaha terhadap program JKN juga masih rendah karena badan usaha menganggap yang akan mendapatkan manfaat lebih besar adalah pekerjanya, pemahaman pimpinan badan usaha terkait kebijakan program JKN masih rendah, dan kelompok yang dijadikan referensi oleh badan usaha mempunyai pengaruh besar untuk tidak menjadi peserta program JKN.

"Ndak ada mbak. Selama ini aman. Hehehe.." (Informan 3, 45 tahun)

Kutipan di atas menunjukkan bahwa selama ini badan usaha tidak pernah 
mendapatkan masalah dari ketidakikutsertaannya pada program JKN yaitu berupa sanksi administratif yang diberikan oleh pihak BPJS Kesehatan. Padahal masalah yang akan dialami badan usaha bukan hanya sanksi administratif tetapi juga produktivitas pekerja yang menurun bila pekerja tidak diberikan jaminan kesehatan. Berdasarkan hal tersebut disimpulkan bahwa proses pengenalan masalah atau kebutuhan badan usaha masih rendah. Hal tersebut didukung penelitian yang menyatakan bahwa konsumen akan memilih untuk mengadopsi suatu produk apabila konsumen sudah memiliki kesadaran atas pentingnya produk [14]. Sikap informan yang belum sadar atas pentingnya program JKN tersebut akan mempengaruhi tahap proses pengambilan keputusan badan usaha selanjutnya.

Tahap selanjutnya adalah pencarian informasi. Pencarian informasi merupakan upaya-upaya yang dilakukan seseorang untuk mendapatkan informasi tentang pogram JKN. Seberapa jauh orang tersebut mencari informasi tergantung pada kuat lemahnya dorongan kebutuhan, banyaknya informasi yang dimiliki, dan kemudahan memperoleh informasi.

\section{"Nggak pernah nyari mbak. Yowes dikasih tahu orang BPJS sama Puskesmas Sumbersari itu wes." (Informan 3, 45 tahun)}

Sebagian besar informan tidak berusaha untuk mencari informasi terkait program JKN sehingga terkesan pasif dalam mendapatkan informasi. Informasi konsumen dikategorikan ke dalam dua dimensi yaitu sumber personal dan sumber impersonal [11]. Sumber informasi pimpinan badan usaha mengenai program JKN yaitu dari sumber personal dan impersonal. Sumber personal yaitu dari petugas BPJS Kesehatan dan pegawai Puskesmas Sumbersari Kabupaten Jember, word of mouth (WOM) dari keluarga, teman serta tetangga. Sumber impersonal yaitu iklan TV. Sumber informasi personal WOM dari keluarga atau teman memang lebih baik bila informasi yang disampaikan benar dan tepat. Tapi pada kenyataannya sumber informasi WOM merupakan sumber yang tidak bisa dikendalikan oleh pemasar (dalam hal ini adalah pihak BPJS Kesehatan) sehingga kadang informasi yang disampaikan berbeda dengan kenyataan yang ada. Di sinilah tugas BPJS Kesehatan untuk memberikan informasi yang benar dan tepat.

Setelah melakukan pencarian dan pemprosesan informasi, langkah berikutnya adalah evaluasi alternatif yaitu melakukan penilaian terhadap informasi yang diperolehnya. Sikap seseorang akan mempengaruhi keputusannya untuk membeli produk jasa atau tidak. Dalam hal ini sikap terhadap produk berarti mempelajari kecenderungan konsumen untuk mengevaluasi produk baik yang disenangi ataupun tidak disenangi. Dalam tahap evaluasi alternatif ini, faktor yang menjadi kriteria utama badan usaha dalam keputusan kepesertaannya pada program JKN adalah persepsinya terhadap karakteristik program JKN yaitu dari kualitas pelayanan kesehatan di fasilitas kesehatan dan masalah finansial yang akan dialami badan usaha bila harus menanggung iuran untuk seluruh pekerja beserta keluarganya.
“...Ya kita bilang ke BPJSnya kalau kita nggak mampu mbak. Masalahnya kita sudah dibebani BPJS Ketenagakerjaan itu. Sekarang itu loh BPJS Ketenagakerjaan aja hampir $70 \%$ kita yang nanggung, 30\%nya karyawane. Lha kalau di sini dibebankan semua apalagi itu kan harus 5\% dari UMR mbak. Ya nggak kuat mbak." (Informan 3, 45 tahun)

Salah satu pimpinan badan usaha lebih memilih mendaftarkan seluruh pekerjanya pada BPJS Ketenagakerjaan karena beranggapan bahwa pekerja lebih membutuhkan perlindungan terhadap kecelakaan kerja. Tidak menutup kemungkinan seorang pekerja yang sakit mengalami kesulitan untuk mengakses pelayanan kesehatan yang disebabkan pekerja tersebut tidak mempunyai BPJS Kesehatan dan tidak mampu untuk membayar sehingga bisa mempengaruhi produktivitas kerjanya. Selain itu pekerja yang sakit akan mengakibatkan absensi pekerja tersebut tinggi sehingga kehilangan waktu kerja dan hal tersebut dapat merugikan perusahaan. Berdasarkan hal tersebut dapat disimpulkan bahwa badan usaha dalam proses evaluasi alternatifnya masih kurang.

Tahap yang terakhir adalah keputusan pembelian. Pada tahap ini telah diawali dengan tahap penilaian berbagai alternatif yang dapat dilihat dari atribut-atribut yang melekat pada suatu produk. Berdasarkan indikasi tersebut pimpinan badan usaha menimbang keuntungan atau kerugian dari produk jasa tersebut dan memutuskan apakah akan membeli atau tidak produk jasa tersebut. Hasil penelitian ini menyatakan bahwa sebagian besar informan utama memutuskan untuk tidak mendaftarkan pekerjanya pada program JKN.

\footnotetext{
"Yakin lah mbak, memang kenyataannya saya ndak mampu..." (Informan 3, 45 tahun)
} 
Dalam prosesnya untuk mengambil keputusan, informan utama membutuhkan sangat sedikit kapasitas kognitif atau kontrol sadar. Hal tersebut bisa dilihat dari proses sebelum pengambilan keputusan yang telah dilakukan pimpinan badan usaha yaitu proses pengenalan masalah atau kebutuhan, proses pencarian informasi dan proses evaluasi alternatif yang seluruh hasilnya masih kurang sehingga dapat disimpulkan bahwa keputusan informan utama termasuk perilaku keputusan rutin. Berdasarkan penelitian menyatakan bahwa semakin otomatis suatu perilaku pilihan, semakin sulit bagi pemasar untuk menyela dan mempengaruhi pilihan konsumen [7]. Bila dianalogikan dengan penelitian ini berarti semakin otomatis badan usaha dalam memutuskan untuk tidak berpartisipasi pada program JKN, maka semakin sulit bagi pihak BPJS Kesehatan untuk menyela dan mempengaruhi pilihan badan usaha tersebut.

c. Output

Output dalam penelitian ini adalah kepesertaan badan usaha pada program JKN. Indikator yang digunakan untuk melihat tingkat keberhasilan program JKN khusus pada kepesertaan badan usaha adalah pentahapan kepesertaan yang telah tercantum dalam Perpres RI No. 111 Tahun 2013 tentang Perubahan atas Perpres No. 12 Tahun 2013 tentang Jaminan Kesehatan, bahwa kewajiban melakukan pendaftaran untuk pemberi kerja ada dua tahap yaitu :

1. Pemberi kerja pada BUMN, usaha besar, usaha menengah, dan usaha kecil wajib mendaftar paling lambat tanggal 1 Januari 2015, dan

2. Pemberi kerja pada usaha mikro wajib mendaftar paling lambat tanggal 1 Januari 2016.

Pada kenyataannya pentahapan tersebut belum terealisasi sampai sekarang. Padahal setidaknya batas pentahapan untuk peserta badan usaha adalah 1 Januari 2016 sehingga untuk saat ini BPJS Kesehatan Kabupaten Jember untuk indikatornya mengacu pada target kepesertaan seluruh masyarakat Indonesia yang sudah harus menjadi peserta program JKN pada tanggal 1 Januari 2019. Hal tersebut sesuai dengan kutipan wawancara informan berikut :

"Kalau untuk targetnya kita langsung.

Langsung di sini dalam artian seluruh

penduduk Indonesia pada 1 Januari 2019 sudah harus terdaftar pada program Jaminan Kesehatan Nasional." (Informan 2, 28 tahun)

Dalam pemenuhan target kepesertaan badan usaha, ada hambatan yang dialami oleh pihak BPJS Kesehatan Kabupaten Jember selain kurangnya pengetahuan badan usaha, yaitu badan usaha yang tidak bersikap baik dengan terlalu banyak memberikan alasan serta ketidakakuratan data yang diberikan oleh badan usaha terkait jumlah pekerja. Oleh sebab itu saat ini BPJS Kesehatan menggunakan metode canvassing, diharapkan metode ini bisa membantu terpenuhinya target kepesertaan badan usaha sebelum tanggal 1 Januari 2019.

Saat ini status kepesertaan ketiga badan usaha yang dijadikan objek penelitian adalah belum menjadi peserta program JKN dengan faktor penyebabnya adalah kurangnya pengetahuan informan dan kondisi finansial badan usaha. Ketiga badan usaha tersebut tidak menerapkan kebijakan yang mengatur tentang kepesertaan jaminan kesehatan untuk pekerjanya. Pimpinan badan usaha membebaskan pekerjanya untuk mendaftar secara mandiri pada program JKN. Hal tersebut bertentangan dengan amanat UU No. 24 Tahun 2011 tentang BPJS yang menyebutkan bahwa pemberi kerja secara bertahap wajib mendaftarkan dirinya, pekerjanya berikut anggota keluarganya sebagai peserta kepada BPJS. Selain itu, mereka juga belum merasakan dampak atau kerugian dari status kepesertaan badan usahanya sehingga mereka beranggapan menjadi peserta program JKN bukan prioritas utamanya.

\section{Simpulan dan Saran}

Berdasarkan hasil penelitian mengenai kajian keputusan badan usaha terhadap kepesertaan JKN, maka dapat ditarik kesimpulan sebagai berikut :

a. Input

Kondisi pengetahuan informan tentang program JKN masih rendah. Persepsi badan usaha terhadap karakteristik program JKN masih rendah. Kebutuhan badan usaha terhadap program JKN masih rendah. Hal tersebut didasarkan dari persepsi manfaat yang dirasakan badan usaha bahwa yang lebih merasakan manfaat dari program JKN adalah pekerja. Agama yang dianut pimpinan badan usaha tidak mempunyai pengaruh dalam pengambilan keputusan terhadap kepesertaan pada program JKN. Badan usaha menilai program JKN bukan dari faktor agama tapi dari segi kebermanfaatannya. Pemahaman badan usaha mengenai kebijakan yang terkait dengan program JKN masih rendah. Kelompok referensi mempunyai pengaruh besar terhadap keputusan badan usaha 
untuk menjadi peserta program JKN, yaitu kelompok primer dan kelompok formal.

b. Proses

Proses pengenalan masalah atau kebutuhan yang dilakukan badan usaha masih rendah. Masalah yang dipertimbangkan oleh badan usaha adalah kerugian yang akan dialami untuk membayar iuran seluruh pekerjanya tanpa mempertimbangkan lebih lanjut masalah yang dialami perusahaan apabila pemenuhan kebutuhan kesejahteraan pekerja rendah. Perilaku pencarian informasi badan usaha terkesan pasif. Pertimbangan yang dilakukan badan usaha hanya pada risiko keuangan tanpa pertimbangan risiko yang lain sehingga diketahui proses evaluasi alternatif badan usaha masih rendah. Dalam prosesnya untuk pengambilan keputusan tidak menjadi peserta program JKN, badan usaha menggunakan sangat sedikit kapasitas kognitif sehingga perilaku keputusan pembeliannya termasuk perilaku keputusan rutin.

c. Output

Status kepesertaan tiga badan usaha pada penelitian ini adalah belum menjadi peserta program JKN dengan faktor penyebabnya adalah kurangnya pengetahuan dan kondisi finansial badan usaha. BPJS Kesehatan Kabupaten Jember dalam pemenuhan target badan usaha sudah tidak menggunakan indikator pentahapan badan usaha melainkan target kepesertaan seluruh masyarakat Indonesia pada tanggal 1 Januari 2019.

Berdasarkan hasil penelitian mengenai kajian keputusan badan usaha terhadap kepesertaan JKN, maka saran yang diberikan oleh peneliti adalah sebagai berikut :

a. Saran bagi badan usaha yaitu untuk mempertimbangkan risiko kerugian yang akan dialami perusahaan bila produktivitas pekerja menurun yang disebabkan tidak diberikannya jaminan kesehatan bagi pekerja dan memahami kebijakan terkait hak bagi pekerja dan kewajiban pemberi kerja.

b. Saran bagi BPJS Kesehatan yaitu untuk segera mengimplementasikan Instruksi Presiden No. 8 tahun 2017 tentang Optimalisasi Pelaksanaan Program JKN. Optimalisasi diantaranya adalah dengan memastikan peserta JKN mendapatkan akses pelayanan jaminan kesehatan yang berkualitas dan perluasan kerjasama dengan fasilitas kesehatan yang memenuhi syarat, meningkatkan kerjasama dengan pemangku kepentingan terkait dalam rangka kepatuhan dan terlaksananya program JKN yang optimal, melakukan pengkajian dan evaluasi regulasi terkait program JKN, serta melakukan pengkajian implementasi program JKN dan memberikan bahan masukan untuk perbaikan kebijakan program JKN.

c. Untuk penelitian selanjutnya dapat melakukan kajian lebih mendalam terkait analisis kebijakan pembayaran iuran program JKN pada badan usaha, kajian mendalam pada peserta program JKN terkait pelayanan kesehatan yang diperoleh dari fasilitas kesehatan, atau tentang pengaruh faktor agama pada kepesertaan program JKN.

\section{Daftar Pustaka}

1. Jawa Pos. 2017. Cost Sharing Bukan SatuSatunya Jalan Kurangi Defisit BPJS Kesehatan. Serial Online: https://www.pressreader.com/indonesia.ja wapos/20171127/281492161629368 Januari 2018).

2. Kemenkes RI. 2014. Buku Pegangan Sosialisai Jaminan Kesehatan Nasional (JKN) dalam Sistem Jaminan Sosial Nasional. Jakarta: Kemenkes RI.

3. Kotler, P. 2009. Manajemen Pemasaran. Jilid 1. Jakarta: Erlangga.

4. Mirawati, E. 2009. Analisis Bauran Pemasaran Jasa Terhadap Keputusan Pasien Memanfaatkan Instalasi Rawat Inap Rumah Sakit Grestelina Makassar Tahun 2009. Jurnal AKK. 1(1): 15-21. http://isjd.pdii.lipi.gp.id/admin/jurnal/ed1 mei 106469_2087-0051.pdf [serial online] [diakses pada 13 Mei 2017].

5. Muthmainah, D.A. 2017. BPJS Kesehatan Defisit Anggaran Rp 5,8 Triliun di Semester l. [serial online] https://www.cnnindonesia.com/ekonomi/20 170719142514-78-228881/bpjs-

kesehatan-defisit-anggaran-rp58-triliun-disemester-i (11 Januari 2018).

6. Peraturan Presiden Republik Indonesia Nomor 111 Tahun 2013. Perubahan Atas Peraturan Presiden Nomor 12 Tahun 2013 Tentang Jaminan Kesehatan. 27 Desember 2017. Lembaran Negara Republik Indonesia Tahun 20013 Nomor 255. Jakarta.

7. Setiadi, N.J. 2008. Perilaku Konsumen, Konsep dan Implikasi Untuk Strategi dan Penelitian Pemasaran. Bogor: Kencana.

8. Sinaga, R. 2006. Faktor-Faktor yang Berhubungan dengan Kunjungan Ulang Pasien Gigi Peserta Askes di Poliklinik Gigi 
9. Rumah Sakit Umum Dr. Djasamen Saragih Pematang Siantar Tahun 2006. Tesis. Medan: Pacasarjana USU.

10. Sofuwan, T.M. dan Nurrahmi, M. 2015. Pengaruh Karakteristik Konsumen terhadap Keputusan Pembelian Produk Asuransi pada PT. Sequislife Insurance Cabang Palembang. Jurnal IImu Manajemen. 5(1). http://jurnal.umpalembang.ac.id/index.php/ilmu_manajem en/article/download/301/273 [serial online] [diakses pada 17 Nopember 2017].

11. Suryani, T. 2012. Perilaku Konsumen (Implikasi pada Strategi Pemasaran). Yogyakarta: Graha IImu.

12. Sutisna. 2012. Perilaku Konsumen dan Komunikasi Pemasaran. Bandung: PT Remaja Posdakarya.

13. Undang-Undang Republik Indonesia Nomor 24 Tahun 2011. Badan Penyelenggara Jaminan Sosial. 13 Oktober 2009. Lembaran Negara Republik Indonesia tahun 2011 Nomor 116. Jakarta.

14. Wijayanto, W.B. 2017. Hubungan Pengetahuan dan Kemampuan Ekonomi Masyarakat Terhadap Aksesibilitas BPJS Kesehatan. Jurnal IImu Kesehatan. 2(2). http://ejournal.stikesaisyah.ac.id/index.php/ jika/ [online] [diakses pada tanggal 9 Januari 2018].

15. Yuliati, L.N. dan Simanjuntak, S. 2011. Persepsi Manfaat dan Risiko dalam Perilaku Pembelian Konsumen Online Shop. Jurnal Ilmu Keluarga dan Konsumen. 4(2): 173-181. ISSN: 1907-6037.

16. Yuniarti, Y. 2015. Pengaruh Kelompok Acuan dan Keluarga Terhadap Keputusan Pembelian Batik Jambi di Kota Jambi. Jurnal Penelitian Universitas Jambi: Seri Humaniora. 17(2): 09-18. ISSN 0852-8349. 